Шуганов Евгений, Магистрант Карагандинский Государственный Технический Университет г. Караганда, Республика Казахстан

E-mail: djonik-shuganov@mail.ru

ORCID ID: 0000-0002-5072-5099

\title{
ИССЛЕДОВАНИЕ ВЛИЯНИЯ СОСТАВОВ И СПОСОБОВ ФОРМИРОВАНИЯ ПЕСЧАНО-СМОЛЯНЫХ ДИСПЕРСНЫХ СМЕСЕЙ НА КАЧЕСТВО ОБОЛОЧКОВЫХ ФОРМ
}

Shuganov Yevgeniy, Master`s Degree student Karaganda State Technical University Karaganda, the Republic of Kazakhstan E-mail: djonik-shuganov@mail.ru ORCID ID: 0000-0002-5072-5099

\section{STUDY OF THE EFFECT OF COMPOSITIONS AND WAYS OF FORMATION SANDY-SMOLE DISPERSED MIXTURES FOR QUALITY SHAPED FORMS}

\begin{abstract}
Annotation: The various compositions of sand-resin mixtures and solutions to improve their physico-mechanical properties are considered. The relationship between technological parameters, composition and properties of the binding components of sand-resin mixtures is shown. An experimental setup for the manufacture of shell molds from sand-resin mixtures is described. The optimal composition of sand-resin mixtures for heating radiator rods is proposed.

Keywords: Sand-resin mixture, binder, model, form, stem, pulverbakelite, phenolformaldehyde.

Аннотация: Рассмотрены различные составы песчано-смоляных смесей и решения по улучшению их физико-механических свойств. Показана взаимосвязь между технологическими параметрами, составом и свойствами связующих компонентов песчано-смоляных смесей. Описана экспериментальная установка для изготовления оболочковых форм из песчано-смоляных смесей. Предложен оптимальный состав песчано-смоляных смесей для стержней отопительных радиаторов.
\end{abstract}

Ключевые слова: Песчано-смоляная смесь, связующее, модель, форма, стержень, пульвербакелит, фенолформальдегид.

Один из основных факторов, гарантирующих конкурентоспособность в литейном производстве, - качество изготовляемых отливок. Основные показатели работы деталей, получаемых из отливок, - их долговечность и надежность. При производстве таких деталей важно уменьшить затраты на их изготовление, не снижая их механические, а также, эксплуатационные свойства. Поэтому, разработка и использование новых технологических процессов для изготовления отливок недорогих и качественных деталей - стратегическая задача. Чтобы сформировать качественную отливку, такие параметры формы, как газопроницаемость, осыпаемость, твердость и другие должны быть оптимальными, чего можно достичь, варьируя состав формы [1].

Известно, что дополнительное приложение нагрузки на песчано-смоляную смесь (ПСС) повышает прочность формы. Проводятся исследования по совершенствованию оборудования, технологии и составов ПСС. Разработаны различные составы ПСС с

Металлургия - составы песчано-смоляных смесей
Материалы Международной практической интернет-конференции «Актуальные Проблемы Науки» 
добавками для повышения прочностных свойств и лучшего распределения смолы по зёрнам песка.

Предложена ПСС, которая содержит, \%: порошкообразное фенолформальдегидное связующее с 3...5 уротропина; кубовый остаток производства гидролизованного топлива, побочный продукт переработки нефтяного сырья, в виде смеси углеводородов разной молекулярной массы - 0,3...0,5; кварцевый песок - остальное.

Такая ПСС позволяет повысить прочность стержней и форм в 1,15-1,4 раза (при хранении готовой смеси в течение 72 часов), кроме того, достигается улучшение антипригарных свойств смеси и снижение склонности её к образованию газовых раковин в отливках, за счёт этого дефектность отливок по пригару снижается, в среднем, в 10 раз и по газовым раковинам - в 4-8 раз [2]. Согласно другому решению, для улучшения физико-механических свойств затвердевшей среды сухую плакированную смесь увлажняют до 0,5...1,5 \%, и увлажнённой смесью заполняют оснастку.

Разработана ПСС для изготовления литейных ОФ и стержней по нагреваемой оснастке, включающая огнеупорный наполнитель, новолачное фенолформальдегидное связующее, совместно с уротропином (марки ПК-104), технологические добавки и органический растворитель связующего. Для повышения прочности ОФ и стержней смесь содержит указанные ингредиенты в следующем соотношении, \%: ПК-104 - 2,0...5,0; технологические добавки $-0,02 \ldots 10,0$; органический растворитель связующего $-2,1 \ldots 2,4$; огнеупорный наполнитель $(\mathrm{OH})$ - остальное.

Для исключения слёживаемости твёрдых частиц смолы при хранении и достижения лучшего её распределения на поверхности зёрен ОН в процессе плакирования связующего использовали водно-восковую дисперсию $30 . .46$ \%-ной концентрации $0,1 \ldots 5,0$ [3].

Предлагается способ получения связующего, включающий новолачную конденсацию фенола и формальдегида в кислой среде, сушку смолы до получения её в виде твёрдых частиц и охлаждение. Отличительная особенность способа в том, что твёрдые частицы смолы покрывают водно-восковой дисперсией $30 \ldots 46$ \%-ной концентрации, с последующей сушкой при температуре на $10 \ldots 30{ }^{\circ} \mathrm{C}$ ниже температуры плавления смолы.

Разработан способ изготовления оболочковых форм (ОФ) или стержней из жидкостекольной суспензии, согласно которому, перед нанесением суспензии изготовляют замороженную модель-стержень, а после формирования оболочки производят её тепловую обработку. Модель-стержень оттаивает, и песок высыпается из полости оболочки. Использование изобретения позволит снизить трудоёмкость при формировании оболочки в 5 раз и уменьшить расход связующего в 2-3 раза, при увеличении прочности оболочек.

Для повышения физико-механических свойств плакированных смесей и снижения себестоимости предлагается в $\mathrm{OH}$ вводить отходы плакированной смеси смесеприготовительного агрегата крупностью 1 мм при следующем соотношении компонентов, \%: кварцевый песок - 10...40; указанные отходы - 60...90.

При изучении влияния солей стеариновой кислоты на прочность плакированной смеси установлено, что максимальное влияние на увеличение сопротивления срезу оказывает стеарат кальция, имеющий меньшую электроотрицательность, по сравнению со стеаратами цинка и алюминия. Можно сделать вывод: чем меньше электроотрицательность атома металла, входящего в состав стеарата, тем больше влияние последнего на прочностные характеристики смесей.

Введение известняковой муки в смесь для ОФ позволяет: повысить прочность отверждённой оболочки (что снижает на $15 . .20$ \% расход пульвербакелита); повысить

Металлургия - составы песчано-смоляных смесей
Материалы Международной практической интернет-конференции «Актуальные Проблемы Науки» 
качество поверхности отливок; сократить припуски на механическую обработку; снизить газотворную способность смеси на $15 \ldots 20 \%$, улучшив, тем самым, санитарногигиенические условия труда.

Такая смесь более устойчива к передвижениям формы при отверждении [4].

Механические испытания металлических образцов показали, что введение известняковой муки приводит к повышению прочностных и пластических свойств отливок.

Исследования процесса формирования твёрдой оболочки из ПСС проводили на экспериментальной модернизированной установке. При проведении экспериментов использовали дисперсные материалы, характеристика которых приведена в таблице 1.

Таблица 1

\begin{tabular}{|c|c|c|c|c|c|c|}
\hline Материал & $\begin{array}{c}\text { Грануло- } \\
\text { метрический } \\
\text { состав, } \\
10^{-3} \mathrm{M}\end{array}$ & $\begin{array}{c}\text { Эквива- } \\
\text { лентный } \\
\text { диаметр } \\
\text { частиц, } \\
10^{-3} \mathrm{M}\end{array}$ & $\begin{array}{c}\text { Плотность, } \\
\kappa г / \mathrm{M}^{3}\end{array}$ & $\begin{array}{c}\text { Скорость } \\
\text { витания } \\
\text { частиц, } \\
\text { м/с }\end{array}$ & $\begin{array}{c}\text { Коэф- } \\
\text { фициент } \\
\text { внутреннего } \\
\text { трения }\end{array}$ & $\begin{array}{c}\text { Порозность } \\
\text { неподвижного } \\
\text { слоя, } \mathrm{M}^{3} / \mathrm{M}^{3}\end{array}$ \\
\hline $\begin{array}{l}\text { Соколовско- } \\
\text { сарбайский } \\
\text { железорудный } \\
\text { концентрат }\end{array}$ & $0,05 \ldots 0,63$ & 0,08 & 3547 & 1,6 & 0,92 & 0,28 \\
\hline $\begin{array}{l}\text { Лисаковский } \\
\text { гравитационно- } \\
\text { магнитный } \\
\text { концентрат }\end{array}$ & $0,05 \ldots 2,5$ & 0,35 & 3199 & 4,3 & 0,88 & 0,36 \\
\hline $\begin{array}{l}\text { Лисаковский } \\
\text { магнитный } \\
\text { концентрат } \\
\text { (обжиг) }\end{array}$ & $0,05 \ldots 0,1$ & 0,07 & 3466 & 1,7 & 0,95 & 0,29 \\
\hline $\begin{array}{l}\text { Оленегорский } \\
\text { суперконцентрат }\end{array}$ & $0,05 \ldots 0,1$ & 0,07 & 3669 & 1,2 & 1,01 & 0,27 \\
\hline
\end{tabular}

Таблица 2

\begin{tabular}{|c|c|c|c|c|c|}
\hline Смесь & \multicolumn{3}{|c|}{ Кварцевый песок марки } & \multirow{2}{*}{ Пульвербакелит } & \multirow{2}{*}{ Керосин } \\
\hline & 1 К0315, \% & 1 К02, \% & 1 К016, \% & & \\
\hline 1 & 70 & 30 & - & $1 \ldots 7$ & $0,2 \ldots 7$ \\
\hline 2 & - & - & 100 & 5 & 1 \\
\hline 3 & - & 100 & - & 5 & 1 \\
\hline 4 & - & 70 & 30 & 5 & 1 \\
\hline 5 & 100 & - & - & $5 \ldots 7$ & 1 \\
\hline
\end{tabular}

Экспериментальная установка для изготовления ОФ из ПСС изготовлена на базе формовочного полуавтомата модели 51713 и состоит из бункера, в который засыпается ПСС, печи, плиты для дополнительного статического приложения нагрузки, стола, на котором установлена электронагреваемая модельная плита с моделью.

На модельной плите монтировали модели радиаторов, на обратной стороне которой имелись пружинные толкатели и электронагревательные приборы. Там же располагался термодатчик, с помощью которого контролировался нагрев плиты до $240 \ldots 260{ }^{\circ} \mathrm{C}$.

На модель устанавливали наполнительную рамку высотой 100 мм, по периметру совпадающую с бункером. В исходном положении модели были накрыты корпусом

Металлургия - составы песчано-смоляных смесей
Материалы Международной практической интернет-конференции «Актуальные Проблемы Науки» 
сушильной печи. Рядом располагался бункер, в который засыпали механическую смесь песка с пульвербакелитом и некоторыми добавками.

Машина может работать как в автоматическом, так и в ручном режимах. Перед работой модельную плиту покрывали разделительным составом, в качестве которого использовали смесь из воды - $100 \%$, мыла хозяйственного - $3 \%$, ПМС (силикон) - 8 \%. В момент нанесения на горячую модель разделительная смесь образует тонкую и твёрдую, но жаростойкую плёнку, которая сохраняется после нескольких съёмов оболочек с моделей.

При включении формовочной машины печь поднималась вверх, из бункера на модельную плиту засыпалась смесь. При этом, на наполнительную рамку с насыпанной смесью опускалась плита, оказывая статическую нагрузку на смесь. Под действием теплоты модельной оснастки пульвербакелит в слое смеси, непосредственно прилегающей к модельной плите, плавился и смачивал зёрна песка.

После получения оболочки плита возвращалась в исходное положение, а модели с оболочкой накрывались печью, внутри которой температура была $350{ }^{0} \mathrm{C}$. Вместо газовых форсунок на печи были установлены электрические спирали. Толщина оболочки составляет 8...12 мм. Составы, использованных в экспериментах смесей, приведены в таблице 2.

Перемешивали ПСС в смешивающих бегунах модели 111 с двумя катками.

В смеситель вначале загружали песок и керосин, которые перемешивали в течение $6 \ldots 8$ минут, затем засыпали пульвербакелит и перемешивали смесь ещё $12 \ldots 15$ минут.

Стержни изготовляли на стержневой пескодувной восьмипозиционной машине карусельного типа модели 4509.

\section{СПИСОК ЛИТЕРАТУРНЫХ ИСТОЧНИКОВ}

1. Куликов В.Ю., Квон Св.С., Е.Н., Еремин Т.В. Ковалева, Адамова Г.Х. Влияние вариативного давления на плотность и прочность песчано-смоляных форм // Литейное производство. - 2018. - № 9. - С.18 - 21 .

2. Максимов Е.В., Капбасов Ш.К., Исагулов А.З., Куликов В.Ю., Ахметова С.С. Структура полидисперсных и пористых систем // Труды университета. - 2004. - № 4.C. $48-52$.

3. А.с. 49000 РК. Способ изготовления оболочковых форм из песчано-смоляной смеси // Исагулов А.З., Куликов В.Ю., Атамбаев Ж.Н., Согрина О.С. и др.

4. Исагулов А.З., Куликов В.Ю., Абдрахманов М.З., Морозов Г.В., Ли А.В. Повышение плотности дисперсной песчано-смоляной среды // Труды Международной научной конференции «Наука и образование - ведущий фактор стратегии «Казахстан. - 2030». Выпуск 2. - Караганда, 2004. - С.104-106.

Металлургия - составы песчано-смоляных смесей
Материалы Международной практической интернет-конференции «Актуальные Проблемы Науки» 